\title{
Anticipated Effects of Climate Change on Coastal Upwelling Ecosystems
}

\author{
A. Bakun • B. A. Black • S. J. Bograd • M. García-Reyes • \\ A. J. Miller • R. R. Rykaczewski • W. J. Sydeman
}

Published online: 7 March 2015

(C) Springer International Publishing AG 2015

\begin{abstract}
Ecosystem productivity in coastal ocean upwelling systems is threatened by climate change. Increases in spring and summer upwelling intensity, and associated increases in the rate of offshore advection, are expected. While this could counter effects of habitat warming, it could also lead to more frequent hypoxic events and lower densities of suitable-sized food particles for fish larvae. With upwelling intensification, ocean acidity will rise, affecting organisms with carbonate structures. Regardless of changes in upwelling, near-surface
\end{abstract}

This article is part of the Topical Collection on Ecological Impacts of Climate Change

\footnotetext{
A. Bakun $(\bowtie)$

Department of Marine Ecosystems and Society, Rosenstiel School of Marine and Atmospheric Science, University of Miami, 4600

Rickenbacker Causeway, Miami, FL 33149, USA

e-mail: ABakun@rsmas.miami.edu
}

B. A. Black

University of Texas Marine Science Institute, 750 Channel View Drive, Port Aransas, TX 78373, USA

\section{S. J. Bograd}

Environmental Research Division, NOAA Southwest Fisheries Science Center, 99 Pacific Street, Suite 255-A, Monterey, CA 93940, USA

M. García-Reyes • W. J. Sydeman

Farallon Institute for Advanced Ecosystem Research, $101 \mathrm{H}$ St. Suite Q, Petaluma, CA 94952, USA

\section{A. J. Miller}

Scripps Institution of Oceanography, University of California San Diego, 9500 Gilman Drive, La Jolla, CA 92093, USA

R. R. Rykaczewski

Department of Biological Sciences and Marine Science Program, University of South Carolina, 701 Sumter Street,

Columbia, SC 29208, USA stratification, turbulent diffusion rates, source water origins, and perhaps thermocline depths associated with large-scale climate episodes (ENSO) maybe affected. Major impacts on pelagic fish resources appear unlikely unless couples with overfishing, although changes toward more subtropical community composition are likely. Marine mammals and seabirds that are tied to sparsely distributed nesting or resting grounds could experience difficulties in obtaining prey resources, or adaptively respond by moving to more favorable biogeographic provinces.

Keywords Climate change $\cdot$ Eastern boundary upwelling systems $\cdot$ Ecosystem effects $\cdot$ Ocean acidity $\cdot$ Hypoxia . Upwelling efficacy

\section{Introduction}

Major coastal upwelling zones exist along the edges of the eastern boundary currents of the Pacific and Atlantic Oceans (Fig. 1a). These eastern boundary upwelling systems (EBUS) are among the most productive of the world's marine ecosystems $[1,2]$. In EBUS, alongshore winds interact with the earth's rotation to force surface waters offshore, thereby pumping (i.e., "upwelling") nutrient-rich deeper waters into the illuminated surface layers in the coastal zone [3,4] where they are available for photosynthesis. The resulting phytoplankton blooms nourish a vigorously productive zooplankton community as well as massive resident populations of small pelagic fish (sardines, anchovies, etc.) that are extremely important to the world's fisheries. These small pelagic fish species often comprise a substantial portion of the total animal biomass in EBUS, and fluctuations in their abundance have both top-down and bottom-up effects [5], serving as a key 


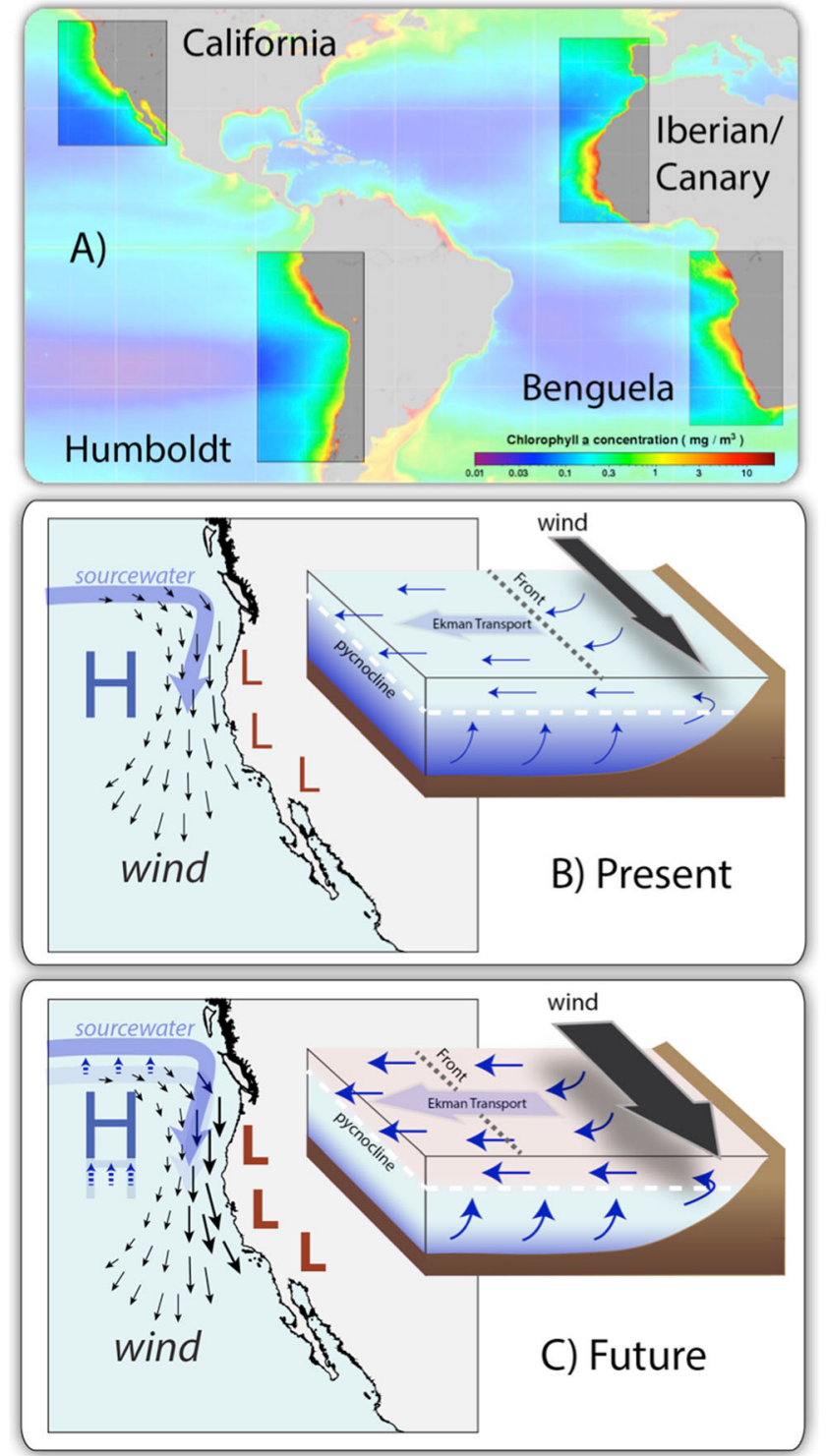

Fig. 1 Summary illustration of anticipated climate change impacts on EBUS. a Global chlorophyll-a annual average concentrations and the locations of major coastal upwelling zones. b Present state of coastal upwelling zones with the California Current as an example. c Potential future state of coastal upwelling zones with the California Current as an example. Anticipated changes include the poleward migration of the Oceanic High and source waters. Continental thermal lows are anticipated to deepen, which will intensify upwelling-favorable (equatorward) winds. Changes in the water column include greater stratification, greater rates of upwelling, and greater offshore transport as well as the offshore migration of the upwelling front

trophic control for large populations of higher trophic-level seabirds, marine mammals, and a variety of commercially important fish. Accordingly, there is much current interest and concern about potential effects of climate change on the ecological functioning, resource productivity, and environmental health of EBUS. Here, we present a vision of potential impacts of climate change on upwelling-ecosystem processes and outline prominent mechanisms that could potentially produce major biological impacts.

For this brief review, we focus on the four principal EBUS [4] of the world, as these appear to present major similarities in essential physical dynamics and ecosystem structures and functions. These are the Benguela Current off southwestern Africa, the Canary Current off northwestern Africa including its northern extension off the Iberian Peninsula of southwestern Europe, the Peru-Humboldt Current off western South America, and the California Current off the western continental USA and northwestern Mexico (Fig. 1a). Our objectives are modest. In moving beyond the realms of invariant physical and chemical laws into the nonlinearly linked, multi-leveled world of complex-adaptive marine biological ecosystems, confident prediction becomes ever more elusive. However, our abilities to employ some degree of intelligent management toward the preservation of the resources, services, and cultural/ esthetic values relative to global change seems sufficiently important to warrant putting faith in informed speculation. As Mark Twain famously commented, "History does not repeat itself, but it does rhyme." Charles Darwin advised that "without speculation there can be no original or true observation." Accordingly, our hope is to provide a useful conceptual template against which observed ecosystem changes may be arranged as they become apparent, thereby aiding efforts in identifying significant changes and societal impacts.

\section{Predicted Physical Changes}

Like many marine ecosystems, EBUS are expected to experience a sequence of alterations associated with heating near the earth's surface, as well as from changes in ocean carbonate chemistry due to the continuing buildup of greenhouse gasses in the earth's atmosphere. The latest assessment of general circulation models (GCMs) forced by increasing greenhouse gas concentrations clearly show warming in the lower troposphere with impacts on surface land and ocean temperatures [6]. Beyond the direct consequences of increasing global ocean temperatures (e.g., increased ocean stratification, altered pathways of subduction, etc.), local-to-regional responses in EBUS temperature fields are likely to show extensive spatial variations due to changing wind distributions and consequential impacts on coastal and offshore upwelling. As one example, GCM predictions indicate that the Hadley Cells that influence the distribution of the pressure systems that force upwelling-favorable winds will be altered in both latitudinal extent and intensity (Fig. 1b, c). The Hadley Cells are predicted to expand poleward in both hemispheres, and observational evidence indicates this has already begun to occur [7, 8]. These changes to the Hadley Cells suggest that the regional EBUS may expand poleward in both hemispheres. Due to the asymmetric response of surface temperatures in the northern 
(more land) and southern (less land) mid-latitude oceans, combined with tropical warming, the Northern Hemisphere Hadley Cell is predicted to decrease in intensity while that of the Southern Hemisphere will increase in intensity [9]. It is still unclear how these future shifts in the Hadley Cell might impact the ocean high-pressure systems [6], which are major drivers of upwelling winds and appear to be largely responsible for their variability [10]. In addition to these dynamical changes in the Hadley Cells, local thermodynamic arguments suggest that regional upwelling winds in the EBUS may increase due to increased land-sea temperature contrast as suggested by Bakun [11], often referred to as the Bakun Hypothesis $(\mathrm{BH})$. The $\mathrm{BH}$ suggests that under global warming, continental temperatures will rise faster during the local heating seasons than will temperatures in the nearby ocean, thereby steepening the cross-shore pressure gradients that drive upwelling-favorable winds (Fig. 1b, c). This idea was originally supported by emerging interregional patterns of observed sea-surface wind stress, and has been periodically tested against time series of observed data in all four regional EBUS [12, 13]. Most recently, using the amassed literature that has tested the $\mathrm{BH}$, Sydeman et al. [14] conducted a meta-analysis that confirms the emergence of a general pattern of increasing reports of positive trends in upwelling-favorable wind intensity in a majority of upwelling regions (California, Benguela, and Humboldt) during past decades during which the concentrations of greenhouse gasses have continued to increase. This pattern of increased upwelling-favorable wind intensity could be due to other climate-related mechanisms, such as natural multi-decadal climate variability, but the likelihood of significant greenhouse gas-related interactions cannot be dismissed. Attempts to test the operation of the $\mathrm{BH}$ mechanism using large grid-scale climate models have had mixed results [15-17], although simulations done with finer spatial resolution climate models of the California system offer evidence that representation of the $\mathrm{BH}$ dynamics may be dependent on model resolution $[18,19]$. Additional regional downscaling of different large grid-scale climate models is needed to obtain ensembles of spatially explicit projections of wind attributes in these systems that could improve consensus. Finally, predictions of physical change are complicated by basin-scale modes of climate variability at interannual to decadal scales that strongly impact upwelling intensity and ocean conditions. The Pacific EBUS are particularly impacted by the El Niño Southern Oscillation (ENSO), with effects on upwelling and across trophic levels in association with strong El Niño and La Niña events. To a smaller scale, the Atlantic is affected by ENSO-like variability (e.g., the Benguela Niño; [20]). In the Canary/Iberian EBUS, variation in the North Atlantic Oscillation (NAO) and Atlantic Multidecadal Oscillation (AMO) impact these ecosystems [21]. The current generation of GCMs has no consensus on whether the statistics of ENSO, Pacific Decadal Oscillation (PDO), NAO, or AMO events will be altered in the future, so any likely changes to their intensity, spatial extent, frequency, and impacts on upwelling within EBUS remain unclear [6, 22].

\section{Biophysical Responses}

Changes to the physical environment of EBUS can directly affect the physiology (e.g., metabolism and respiration) of marine life with impacts on growth, reproductive capacity, and behavior. As metabolic rates increase with temperature, fish growth may be enhanced with ocean warming, but warming may also have direct negative impacts on the production of phytoplankton and zooplankton. For many fish species, the greatest risk from climate change may operate during larval and/or juvenile stages, when survival and recruitment are strongly dependent on having sufficient planktonic food resources at the right time and place [23-27]. If changes to physiological functions are substantial, variation in species' abundances can translate into changes in productivity, phenology, and community composition, hence interspecific relationships and ecosystem functions [28]. Some of the most critical impacts may include changes to habitat characteristics upon which fish and other upper trophic level species depend. Indeed, the effects of climate change operating through habitat or food web variation is thought to be already significant for many species of commercially valuable fish and wildlife [29-33].

\section{Enhanced Coastal Upwelling}

Intensified upwelling-favorable winds [11] would lead to an increased upwelling rate, greater turbulence in the upper ocean, and swifter offshore transport of surface waters. With low to moderately strong upwelling, upwelled nutrients would support a robust phytoplankton community (Fig. 2), which would in turn sustain flourishing zooplankton and upper trophic level communities. While enhanced upwelling may lead to enhanced nutrient enrichment, the increased intensity of upwelling-favorable winds could lead to less phytoplankton production within the primary upwelling zone due to deeper wind-driven mixing of the water column and increased light limitation. In addition, changes in species composition of phytoplankton and zooplankton communities are a likely result that in turn may impact successively higher levels of the trophic web.

\section{Enhanced Offshore Transport}

With strongly enhanced upwelling, the rate of offshore transport of surface waters would increase, potentially leading to problematic consequences. Phytoplankton and zooplankton would be transported more rapidly toward convergent 


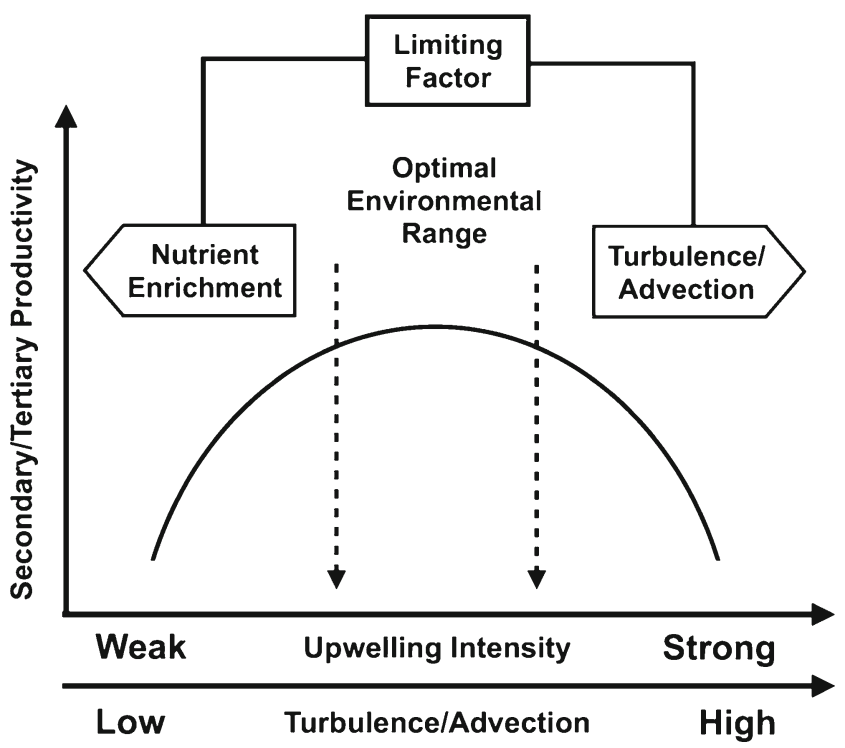

Fig. 2 The "optimal environmental window" shows highest levels of productivity at moderate upwelling intensity. When upwelling is strong, biota can be advected offshore, while at low upwelling intensity nutrients in the upper water column can be limiting to productivity. Adapted from reference [86]

offshore frontal systems, which themselves may be forced further offshore (Figs. 1b, c and 2) [3, 34, 35]. Under this scenario, positively buoyant planktonic organisms or other organisms able to maintain a preferred depth (e.g., euphausiid crustaceans and large-bodied copepods) could become progressively concentrated as the waters in which they are entrained converge horizontally and are thereby driven downward. The resulting concentrated food resource could attract planktivorous seabirds (e.g., auklets and shearwaters), small pelagic fishes and other nekton, marine mammals (e.g., balaenopterid whales), and their predators. Furthermore, the marked difference in ontogeny, generation times, and swimming capabilities between phytoplankton and zooplankton may result in a spatial mismatch between herbivorous zooplankton and their phytoplankton forage, and/or flushing of any weakly mobile organisms from favorable habitats associated with the near-coastal upwelling zone [36]. If the planktonic grazers that otherwise would exert control on phytoplankton growth are displaced, and the nutrient supply remains high, rapidly reproducing phytoplankton may become more abundant. Consequently, the total amount and offshore extent of new primary production might increase.

\section{Changes in Ocean Vertical Structure}

Upper ocean warming could increase water column stratification [37-39], potentially counteracting the effects of intensifying upwelling-favorable winds by reducing the efficacy of coastal upwelling to deliver nutrients to the euphotic zone. This mechanism was modeled by Chhak and Di Lorenzo [40] who showed shallow, presumably nutrient-poor, source waters are associated with weaker winds and enhanced stratification during warm conditions in EBUS. Enhanced stratification in the southern part of the California Current has been implicated in the observed long-term decline in zooplankton biomass [38, 41], although this decline has been attributed primarily to a change in the abundance of pelagic tunicates $[42,43]$. Some modeling studies [e.g., 44] also suggest that the increase in upwelling-favorable winds could effectively counteract enhanced thermal stratification. The interplay among stratification, the depth and origin of upwelled waters, and the strength of upwelling winds are unresolved questions pertaining to understanding nutrient fluxes and productivity in EBUS.

\section{Remote Stratification/Ventilation and Source Waters Changes}

Biogeochemical properties of waters entering upwelling zones can have significant influence on local biological processes. Variability in source waters may be classified into two categories: 1) changes in the properties of surface waters that are supplied to the poleward regions of the predominant equatorward-flowing eastern boundary currents and 2) changes in properties of deep and remote source waters that are eventually upwelled from below the pycnocline. Surface waters of the poleward limbs of the subtropical gyres (e.g., the North Pacific Current), which are driven by the surface winds and are expected to shift poleward under global warming (see section 2), supply a substantial portion of the surface waters in EBUS (Fig. 1b, c). Over interannual to decadal time scales, increased zooplankton biomass [45-47] and variability in the productivity and abundance of zooplankton, fishes, and higher predators of the California Current have been attributed to the meridional position of the North Pacific Current [48-50]. Given a general meridional gradient in surface nutrient, phytoplankton, and zooplankton concentrations (with greater concentrations found at more poleward locations), poleward displacement of zonal currents with global warming may supply the poleward endpoints of EBUS with more nutrients and larger plankton populations advected into the poleward regions of EBUS.

Regarding the second mechanism, water masses upwelled by coastal winds are rich in nutrients in part because of the relatively long time period during which these water masses were below the euphotic zone. Model experiments tracing the history of these waters in the North Pacific indicate that they are subducted from the surface layer at locations well offshore of the EBUS and may remain at depth for decades prior to being upwelled, in the meantime accumulating remineralized nutrients and carbon dioxide while oxygen is being consumed by respiration [51]. The general expectation of increased vertical stratification and decreased mixing in the source regions, particularly during winter cooling seasons, may further limit the ventilation of these water masses under global warming. 
As a result, deep waters supplied in the future by upwelling may be characterized by increased macronutrient concentrations, reduced $\mathrm{pH}$, and decreased oxygen concentrations. While nutrient content may enhance productivity, reduced oxygen and $\mathrm{pH}$ could negatively impact ecosystem functions (see next section). Potential feedbacks between local biological production and biogeochemical properties of source waters should be considered in new regional climate models.

\section{Hypoxia, Dead Zones, and Acidification}

As a result of enhanced stratification and reduced ventilation, next generation GCMs predict a decline in dissolved oxygen with high certainty [37, 52, 53]; large-scale ocean circulation could advect these modified deep waters into EBUS [54]. A reduction in mid-depth dissolved oxygen content results in a shoaling of the oxygen minimum zones to depths from which upwelled waters are derived. A long-term trend toward declining oxygen content in the southern California Current has been observed, with the hypoxic boundary (defined as the depth at which dissolved oxygen is $60 \mathrm{uM} / \mathrm{kg}$ ) shoaling by up to $80 \mathrm{~m}$ over the period 1984-2006 in the Southern California Bight $[55,56]$. Benthic organisms found in regions where a low oxygen layer intersects the continental margin could be directly impacted [57], while pelagic species could find their viable habitats significantly compressed $[55,56$, 58-60].

Increasing occurrences of hypoxia are expected due to enhanced coastal productivity and subsequent increases in respiration, combined with generally lower levels of dissolved oxygen at depth on the inner continental shelf $[61,62]$. In the northern California Current, hydrographic observations have revealed a recent increase in the frequency and severity of hypoxic events, and even occasional water column anoxia, on the inner continental shelf $[61,62]$. The biological impacts of these events can be catastrophic, with widespread mortality of macroscopic benthic organisms, resulting in periodic dead zones such as those observed on the Oregon continental shelf [61]. Other species, such as Humboldt squid, which have migrated north into the California Current in recent years [63], may be able to take advantage of low-oxygen environments.

In anoxic zones, methane $\left(\mathrm{CH}_{4}\right)$ bubbles formed at depth as a by-product of anoxic respiration can collect poisonous hydrogen sulfide gas $\left(\mathrm{H}_{2} \mathrm{~S}\right)$, and carry it upward to the oxygenated ocean layers and atmosphere in massive submarine eruptions. Such events, some extending over more than 20 , $000 \mathrm{~km}^{2}$ of ocean surface [64-68], have been repeatedly observed near the coast of Namibia, resulting in widespread mortality of marine life and corrosive, foul-smelling emissions over land. The importance of this phenomenon in EBUS beyond the Benguela system has not been examined, though the entire northern sector of the Arabian Sea, an upwelling region, has been identified as a major zone of methane emissions [69-71].

Another consequence of rising atmospheric $\mathrm{CO}_{2}$ concentrations is the reduction in oceanic $\mathrm{pH}$ via the dissolution of $\mathrm{CO}_{2}$ into seawater. This process will lead to more acidic waters which will make it increasingly difficult for important lower trophic level marine organisms, such as oysters and pteropods, to precipitate calcium carbonate $\left(\mathrm{CaCO}_{3}\right)$ to form shells and exoskeletons [72-74]. Impacts on calcareous plankton may reduce prey availability for fish while failures in bivalve reproduction could substantially alter intertidal and benthic habitat. Seasonal upwelling of low-pH ("corrosive") waters has been observed in the California Current [74-76], but GCMs may fail to accurately project ocean acidification due to their lack of detail in fine-scale atmosphere-ocean dynamics related to upwelling; future projections as to the growth of acidification in EBUS remain uncertain.

\section{Trophic Interactions, Match-Mismatch, and Phenological} Responses

Changes in the timing and amplitude of coastal upwelling, i.e., phenological changes, can have profound impacts on the EBUS [e.g., 41]. This was particularly evident in 2005 in the California Current, when a significant delay in the spring transition [77, 78] appears to have led to ecosystem changes affecting primary production [79], to zooplankton [80], to fish, birds, and mammals [81-83]. These ecosystem disruptions may be associated with mismatches between physical forcing and the productivity and life cycles of predator and prey [23, 84]. Related to the concept of spring transition, upwelling winds in the California Current occur in distinct winter and summer seasonal "modes," each with unique atmospheric drivers [10] and differential impacts on biological processes, as documented in rockfish (Sebastes spp.) growth and seabird reproductive success [85]. Changes to the timing of these modes and transitions may be biologically relevant and need to be more thoroughly studied using coupled climate models. New comparative research on seasonal modes of upwelling and ecosystem consequences between the California and Benguela systems is now underway.

\section{Upper Trophic Responses}

\section{Commercially Important Fish Populations}

Mid trophic level biomass in upwelling systems is generally dominated by extremely large populations of one to several species of small pelagic planktivorous "forage" fish (anchovies, sardines, etc.). The relationship between upwelling and productivity in these species is thought to be dome-shaped (Fig. 2) [86]. When upwelling is weak, limited nutrient input 
restricts primary and secondary productivity. Yet when upwelling is too strong, turbulence and offshore advection could decrease fish production due to disruption of feeding strata $[87,88]$ and/or excessive offshore transport of planktonic larvae and prey away from favorable coastal habitats $[86,89]$. Moderate upwelling is thought to result in maximum production of this key small pelagic fish component, a concept that is known as the optimal environmental window hypothesis [86]. Similarly, the best fish production may occur when the timing or spatial distribution of prey is well-matched to the ecological needs of the (fish) predators; this is known as the match-mismatch hypothesis [23] and has been applied to cod stocks in the North Sea [90] as well as salmon and seabirds in California $[82,91]$. Based on a regional climate model, upwellingfavorable wind stress curl off northern California is hypothesized to shift to later in the year in response to an increase in $\mathrm{CO}_{2}$ concentrations [19]. This may have negative impacts on the survival of larvae spawned during fixed periods earlier in the year. For example, it is thought that many rockfish in southern and central California release young in the winter to avoid the turbulent and advective periods later in the year when upwelling is at its peak. If the timing of upwelling changes, a temporal mismatch between fish larvae and their food may reduce survival. In another example, delayed transition to upwelling is hypothesized to have resulted in a temporal mismatch between arrival of coho salmon smolts at sea and food production from upwelling [92]. Finally, another hypothetical response may be that climate change and overfishing might jointly promote explosive population growth of less mobile and anoxia-tolerant planktivorous jellyfish [93-96].

\section{Seabirds and Marine Mammals}

Seabirds and marine mammals are abundant and diverse in EBUS. These species garner tremendous public support for marine ecosystem conservation and interest in relation to climate change impacts. It is difficult to confidently forecast exactly how climate change will affect productivity, survivorship, or populations of upper trophic level marine organisms. However, changes in these species may be amplified in comparison to changes in lower trophic levels [97, 98], and therefore, they serve as excellent indicators (high signal-to-noise ratio) of climate-ecosystem shifts [82]. Clearly, changes in temperature or ocean chemistry (oxygen concentrations or $\mathrm{pH})$ are unlikely to directly affect physiological functions of upper trophic level species, so most climate change impacts on them are likely to operate indirectly via shifts in habitat characteristics or food web quality [32]. Changes in habitat qualities are highly likely to result in range shifts and redistributions [99], though a recent meta-analysis demonstrated that redistributions have been well documented only for fish [33]. Among seabirds, recent reductions in productivity (breeding success) and populations have been related to climate change in the California [14, 100] and Humboldt [101] systems via changes in anchovy and juvenile rockfish (Sebastes spp.) food resources. Redistributions of seabird populations have been documented in the Benguela system, related to changes in anchovy and sardine prey resources there [102]. Of particular concern for seabirds is that they require nesting sites on opportune, appropriately configured islands. Similarly, seals and other pinnipeds may require protected beaches where they can safely "haul out" to rest and to bear and care for pups. If climate change results in prey species moving away from the available protected nesting and rearing sites, the seabirds and marine mammal populations may no longer be viable components of the regional ecosystems. However, the ongoing and potential effects of climate change on EBUSassociated marine mammals have been less intensively studied than in the case of seabirds. In one example, Salvadeo et al. [103] related a redistribution of Pacific white-sided dolphins in the Gulf of California to ocean warming. Despite high levels of conservation concern, the impacts of climate change on seabirds and mammals remain relatively under-studied.

\section{Ecosystem Variability}

EBUS are known to be highly variable across a wide spectrum of spatial and temporal scales, in both the forcing and response of the system. In some cases, a climate event can force large, temporary changes in overall productivity or community composition; these effects were seen during the large 1997-98 El Niño event [104] and the delayed upwelling in 2005 [78] in the California Current. In other cases, climate-driven regime shifts can alter the overall community structure of the system, changing, for example, a sardine-dominated forage base to one dominated instead by anchovies [105]. EBUS can therefore be characterized as both resilient (quick recovery from disturbances) and robust (maintenance of ecosystem function and relatively high productivity) to natural climate variability, maintaining an abundance of species of high commercial and conservation value. However, the scale of future responses to anthropogenic climate change may be beyond the historical scales of variability [106], making forecasting the response of EBUS to climate change difficult.

\section{Summary}

Figure 1 highlights some of the potential climate-driven changes in EBUS. In summary:

1. A possible tendency for increased coastal upwelling intensity as climate change proceeds could partially buffer coastal upwelling ecosystems from the increases in 
temperature and decreases in nutrient supply that may impact other types of regional-scale ocean ecosystems.

2. There are many possible biological impacts in EBUS including,

- Spatial or temporal (phenological) mismatch between production and consumption,

- Changes in composition or intensity of primary productivity, with direct trophic linkages to and subsequent changes in community composition of heterotrophs,

- Redistribution of populations through habitat changes, and

- Geochemical impacts on biology via noxious gas, acidification, and lack of oxygen.

3. The high intrinsic variability in EBUS suggests that they may be resilient to the changes we have discussed here in the absence of over-exploitation or additional major anthropogenic impacts (e.g., pollution).

4. Exceptions to this conclusion may occur as a result of shifts toward increasing dominance by zooplanktivores (jellyfish, etc.) [93-95].

5. An increasing incidence of hypoxia or anoxic events is likely to lead to the increased occurrence of dead zones, noxious gas emissions, and vertical compression of suitable habitats.

6. There appears to be potential for highly visible mortalities and population declines as megafauna (seabirds, pinnipeds, etc.) adjust to changes in prey distributions relative to suitable nursery locations. Other more versatile components that may be less tied to predator-free shore zones might successfully exploit opportune ecological "loopholes" that develop.

7. EBUS are highly resilient and robust, yet the impacts of climate change could be profound and difficult to forecast as they begin to exceed recent millennial ranges of precedent variability.

Acknowledgments We thank S.A. Thompson for editing, formatting, and referencing this paper. AJM thanks NSF for funding under grants OCE-1026607, OCE-0960770 and OCE-1419306. BAB, WJS, MGR, RRR and SJB thank NSF for funding under grant OCE- 1434732.

\section{References}

1. Ryther JH. Photosynthesis and fish production in the sea. Science. 1969;166:72-6.

2. Cushing DH. Upwelling and fish production. FAO Fish Tech Pap. 1969;84:40.

3. Sverdrup HU. On the process of upwelling. J Mar Res. 1938;1:15564.
4. Wooster WS, Reid JL. Eastern boundary currents. In: Hill MN, editor. The sea, vol. 2. New York: Interscience Pub; 1963. p. 253 80

5. Schwartzlose RA, Alheit J, Bakun A, et al. Worldwide large-scale fluctuations of sardine and anchovy populations. S Afr J Mar Sci. 1999;21:289-347.

6. Stocker TF, Qin D, Plattner G-K, et al. Technical summary. In: Stocker TF, Qin D, Plattner G-K, et al., editors. Climate change 2013: the physical science basis. Contribution of working group I to the fifth assessment report of the intergovernmental panel on climate change. Cambridge: Cambridge University Press; 2013.

7. Lu J, Vecchi GA, Reichler T. Expansion of the Hadley cell under global warming. Geophys Res Lett. 2007;34:L06805.

8. Seager R, Naik N, Vecchi GA. Thermodynamic and dynamic mechanisms for large-scale changes in the hydrological cycle in response to global warming. J Clim. 2010;23:4651-68.

9. Ma J, Xie S-P. Regional patterns of sea surface temperature change: a source of uncertainty in future projections of precipitation and atmospheric circulation. J Clim. 2013;26:2482-501.

10. García-Reyes M, Sydeman WJ, Black BA, et al. Relative influence of oceanic and terrestrial pressure systems in driving upwellingfavorable winds. Geophys Res Lett. 2013;40:5311-5.

11. Bakun A. Global climate change and intensification of coastal ocean upwelling. Science. 1990;247:198-201.

12. Barton ED, Field DB, Roy C. Canary current upwelling: more or less? Prog Oceanogr. 2013;116:167-78.

13. Cropper TE, Hanna E, Bigg GR. Spatial and temporal seasonal trends in coastal upwelling off Northwest Africa, 1981-2012. Deep-Sea Res Pt I. 2014;86:94-111.

14. Sydeman WJ, García-Reyes M, Schoeman DS, Rykaczewski RR, Thompson SA, Black BA, et al. Climate change and wind intensification in coastal upwelling ecosystems. Science. 2014;345:77-80.

15. Goubanova K, Echevin V, Dewitte B, Codron F, Takahashi K, Terray $\mathrm{P}$, et al. Statistical downscaling of sea-surface wind over the Peru-Chile upwelling region: diagnosing the impact of climate change from the IPSL-CM4 model. Clim Dyn. 2011;36:1365-78.

16. Belmadani A, Echevin V, Codron F, Takahashi K, Junquas C. What dynamics drive future wind scenarios for coastal upwelling off Peru and Chile? Clim Dyn. 2014;43:1893-914.

17. Miranda PMA, Alves JMR, Serra N. Climate change and upwelling: response of Iberian upwelling to atmospheric forcing in a regional climate scenario. Clim Dyn. 2013;40:2813-24.

18. Mote PW, Mantua NJ. Coastal upwelling in a warmer future. Geophys Res Lett. 2002;29:2138.

19. Snyder MA, Sloan LC, Diffenbaugh NS, Bell JL. Future climate change and upwelling in the California Current. Geophys Res Lett. 2003;30:1823-6.

20. Shannon LV, Boyd AJ, Brundrit GB, Tauntonclark J. On the existence of an El Niño-type phenomenon in the Benguela System. J Mar Res. 1986;44:495-520.

21. Pérez FF, Padin XA, Pazos Y, et al. Plankton response to weakening of the Iberian coastal upwelling. Glob Change Biol. 2010;16:125867.

22. Collins M, An S-I, Cai W, et al. The impact of global warming on the tropical Pacific ocean and El Niño. Nat Geosci. 2010;3:391-7.

23. Cushing DH. Plankton production and year-class strength in fish populations - an update of the match-mismatch hypothesis. Adv Mar Biol. 1990;26:249-93.

24. Landeira JM, Lozando-Soldevilla F, Hernandez-León S. Temporal and alongshore distribution of decapod larvae in the oceanic island of Gran Canaria (NW Africa). J Plankton Res. 2012;35:309-22.

25. Grémillet D, Lewis S, Drapeau L, et al. Spatial match-mismatch in the Benguela upwelling zone: should we expect chlorophyll and sea-surface temperature to predict marine predator distributions? J Appl Ecol. 2008;45:610-21. 
26. Alheit J, Niquen M. Regime shifts in the Humboldt Current ecosystem. Prog Oceanogr. 2004;60:201-22.

27. Houde ED. Emerging from Hjort's shadow. J Northwest Atl Fish Sci. 2008;41:53-70

28. Parmesan C. Ecological and evolutionary responses to recent climate change. Annu Rev Ecol Evol Syst. 2006;37:637-69.

29. Perry AL, Low PJ, Ellis JR, Reynolds JD. Climate change and distribution shifts in marine fishes. Science. 2005;308:1912-5.

30. Mueter FJ, Litzow MA. Sea ice retreat alters the biogeography of the Bering Sea continental shelf. Ecol Appl. 2008;18:309-20.

31. Cheung WWL, Lam VWY, Sarmiento JL, Kearney K, Watson R, Zeller D, et al. Large-scale redistribution of maximum fisheries catch potential in the global ocean under climate change. Glob Change Biol. 2010;16:24-35.

32. Sydeman WJ, Thompson SA, Kitaysky A. Seabirds and climate change: roadmap for the future. Mar Ecol Prog Ser. 2012;454: 107-17.

33. Poloczanska ES, Brown CJ, Sydeman WJ, et al. Global imprint of climate change on marine life. Nat Clim Chang. 2013;3:919-25.

34. Barth JA. Stability of a coastal upwelling front. 2. Model results and comparison with observations. J Geophys Res. 1989;94:10857-83.

35. Marañón E, Fernández E. Changes in phytoplankton ecophysiology across a coastal upwelling front. J Plankton Res. 1995;17:19992008.

36. Bakun A, Weeks SJ. Greenhouse gas buildup, sardines, submarine eruptions, and the possibility of abrupt degradation of intense marine upwelling ecosystems. Ecol Lett. 2004;7:1015-23.

37. Sarmiento JL, Hughes TMC, Stouffer RJ, Manabe S. Simulated response of the ocean carbon cycle to anthropogenic climate warming. Nature. 1998;393:245-9.

38. Roemmich D, McGowan J. Climatic warming and the decline of zooplankton in the California Current. Science. 1995;267:1324-6.

39. Palacios DM, Bograd SJ, Mendelssohn R, Schwing FB. Long-term and seasonal trends in stratification in the California Current, 1950 1993. J Geophys Res. 2004;109:C10016.

40. Chhak K, Di Lorenzo E. Decadal variations in the California Current upwelling cells. Geophys Res Lett. 2007;34:L14604.

41. McGowan JA, Bograd SJ, Lynn RJ, Miller AJ. The biological response to the 1977 regime shift in the California Current. Deep-Sea Res Pt II. 2003;50:2567-2582.

42. Lavaniegos BE, Ohman MD. Long-term changes in pelagic tunicates of the California Current. Deep-Sea Res Pt II. 2003;50:247398.

43. Lavaniegos BE, Ohman MD. Coherence of long-term variations of zooplankton in two sectors of the California Current system. Prog Oceanogr. 2007;75:42-69.

44. Auad G, Miller A, Di Lorenzo E. Long term forecast of oceanic conditions off California and biological implications. J Geophys Res. 2006;111:C09008.

45. Wickett WP. Ekman transport and zooplankton concentration in the North Pacific Ocean. J Fish Res Board Can. 1967;24:581-94.

46. Chelton DB, Davis RE. Monthly mean sea-level variability along the west coast of North America. J Phys Oceanogr. 1982;12:75784.

47. Chelton DB, Bernal PA, McGowan JA. Large-scale physical and biological interaction in the California Current. J Mar Res. 1982;40: 1095-125.

48. Keister JE, Di Lorenzo E, Morgan CA, Combes V, Peterson WT. Zooplankton species composition is linked to ocean transport in the Northern California Current. Glob Change Biol. 2011;17:2498511.

49. Bi H, Peterson WT, Strub PT. Transport and coastal zooplankton communities in the northern California Current system. Geophys Res Lett. 2011;38:L12607.

50. Sydeman WJ, Thompson SA, Field JC, Peterson WT, Tanasichuk RW, Freeland HJ, et al. Does positioning of the North Pacific current affect downstream ecosystem productivity? Geophys Res Lett. 2011;38:L12606.

51. Rykaczewski RR, Dunne JP. Enhanced nutrient supply to the California Current ecosystem with global warming and increased stratification in an earth system model. Geophys Res Lett. 2010;37. L21606.

52. Keeling RF, Garcia HE. The change in oceanic $\mathrm{O} 2$ inventory associated with recent global warming. Proc Natl Acad Sci U S A. 2002;99:7848-53.

53. Keeling RF, Kortzinger A, Gruber N. Ocean dexoygenation in a warming world. Ann Rev Mar Sci. 2010;2:199-299.

54. Deutsch C, Emerson S, Thompson L. Fingerprints of climate change in North Pacific oxygen. Geophys Res Lett. 2005;32: L16604.

55. Bograd SJ, Castro CG, Di Lorenzo E, Palacios DM, Bailey H, Gilly $\mathrm{W}$, et al. Oxygen declines and the shoaling of the hypoxic boundary in the California Current. Geophys Res Lett. 2008;35:L12607.

56. McClatchie S, Goericke R, Cosgrove R, Auad G, Vetter R. Oxygen in the Southern California bight: multidecadal trends and implications for demersal fisheries. Geophys Res Lett. 2010;37:L19602.

57. Levin LA. Oxygen minimum zone benthos: adaptation and community response to hypoxia. Oceanogr Mar Biol. 2003;41:1-45.

58. Stramma L, Schmidtko S, Levin LA, Johnson GC. Ocean oxygen minima expansions and their biological impacts. Deep-Sea Res Pt I. 2010;57:587-95.

59. Stramma L, Prince ED, Schmidtko S, et al. Expansion of oxygen minimum zones may reduce available habitat for tropical pelagic fishes. Nat Clim Chang. 2012;2:33-7.

60. Koslow JA, Goericke R, Lara-Lopez A, Watson W. Impact of declining intermediate-water oxygen on deepwater fishes in the California Current. Mar Ecol Prog Ser. 2011;436:207-18.

61. Grantham BA, Chan F, Nielsen KJ, Fox DS, Barth JA, Huyer A, et al. Upwelling-driven nearshore hypoxia signals ecosystem and oceanographic changes in the northeast Pacific. Nature. 2004;429: 749-54.

62. Chan F, Barth JA, Lubchenco J, Kirincich A, Weeks H, Peterson WT, et al. Emergence of anoxia in the California Current large marine ecosystem. Science. 2008;319:920.

63. Stewart JS, Hazen EL, Foley DG, Bograd SJ, Gilly WF. Marine predator migration during range expansion: Humboldt squid (Dosidicus gigas) in the northern California Current system. Mar Ecol Prog Ser. 2012;471:135-50.

64. Weeks SJ, Currie B, Bakun A, Peard KR. Hydrogen sulfide eruptions in the Atlantic Ocean off southern Africa: implications of a new view based on SeaWiFS satellite imagery. Deep-Sea Res Pt I. 2004;51:153-72.

65. Emeis K-C, Brüchert V, Currie B, et al. Shallow gas in shelf sediments off the Namibian coastal upwelling ecosystem. Cont Shelf Res. 2004;24:627-42.

66. Hamukuaya H, O'Toole MJ, Woodhead PJM. Observations of severe hypoxia and offshore displacement of cape hake over the Namibian shelf in 1994. S Afr J Mar Sci. 1998;19:57-9.

67. Kuypers MMM, Lavik G, Woebken D, et al. Massive nitrogen loss from the Benguela upwelling system through anaerobic ammonium oxidation. Proc Natl Acad Sci U S A. 2005;102:6478-83.

68. Dugdale RC, Goering JJ, Barber RT, Smith RL, Packard TT. Denitrification and hydrogen sulfide in Peru upwelling during 1976. Deep-Sea Res Pt I. 1977;24:601-8.

69. Owens NJP, Law CS, Mantoura RFC, Burkill PH, Llewellen CA. Methane flux to the atmosphere from the Arabian Sea. Nature. 1991;354:293-6.

70. Bange HW, Ramesh R, Rapsomanikis S, Andreae MO. Methane in surface waters of the Arabian Sea. Geophys Res Lett. 1998;25: $3547-50$. 
71. Patra PK, Lal S, Venkataramani S, Gauns M, Sarma VVSS. Seasonal variability in distribution and fluxes of methane in the Arabian Sea. J Geophys Res. 1998;103:1167-76.

72. Doney SC, Fabry VJ, Feely RA, Kleypas JA. Ocean acidification: the other CO2 problem. Ann Rev Mar Sci. 2009;1:169-92.

73. Doney SC. The growing human footprint on coastal and open-ocean biogeochemistry. Science. 2010;328:1512-6.

74. Gruber N, Hauri C, Lachkar Z, Loher D, Frolicher TL, Plattner G-K. Rapid progression of ocean acidification in the California current system. Science. 2012;337:220-3.

75. Feely RA, Sabine CL, Hernandez-Ayon JM, Ianson D, Hales B. Evidence for upwelling of corrosive "acidified" water onto the continental shelf. Science. 2008;320:1490-2.

76. Leinweber A, Gruber N. Variability and trends of ocean acidification in the Southern California Current System: a time series from Santa Monica Bay. J Geophys Res. 2013;118:3622-33.

77. Schwing FB, Bond NA, Bograd SJ, Mitchell T, Alexander MA, Mantua N. Delayed coastal upwelling along the US West coast in 2005: a historical perspective. Geophys Res Lett. 2006;33:L22S01.

78. Barth JA, Menge BA, Lubchenco J, et al. Delayed upwelling alters nearshore coastal ocean ecosystems in the northern California Current. Proc Natl Acad Sci U S A. 2007;104:3719-24.

79. Thomas AC, Brickley P. Satellite measurements of chlorophyll distribution during spring 2005 in the California Current. Geophys Res Lett. 2006;33:L22S05.

80. Mackas DL, Peterson WT, Ohman MD, Lavaniegos BE. Zooplankton anomalies in the California Current system before and during the warm ocean conditions of 2005. Geophys Res Lett. 2006;33:L22S07.

81. Brodeur RD, Ralston S, Emmett RL, Trudel M, Auth TD, Phillips AJ. Anomalous pelagic nekton abundance, distribution, and apparent recruitment in the northern California Current in 2004 and 2005. Geophys Res Lett. 2006;33:L22S08.

82. Sydeman WJ, Bradley RW, Warzybok P, et al. Planktivorous auklet Ptychoramphus aleuticus responses to ocean climate, 2005: unusual atmospheric blocking? Geophys Res Lett. 2006;33:L22S09.

83. Weise MJ, Costa DP, Kudela RM. Movement and diving behavior of male California sea lion (Zalophus californianus) during anomalous oceanographic conditions of 2005 compared to those of 2004. Geophys Res Lett. 2006;33:L22S10.

84. Durant JM, Hjermann DO, Ottersen G, Stenseth NC. Climate and the match or mismatch between predator requirements and resource availability. Clim Res. 2007;33:271-83.

85. Black BA, Schroeder ID, Sydeman WJ, Bograd SJ, Wells BK, Schwing FB. Winter and summer upwelling modes and their relevance to climate impacts and ecological response in the California Current ecosystem. Glob Chang Biol. 2011;17:2536-45.

86. Cury P, Roy C. Optimal environmental window and pelagic fish recruitment success in upwelling areas. Can J Fish Aquat Sci. 1989;46:670-80.

87. Lasker R. Field criteria for survival of anchovy larvae: the relation between inshore chlorophyll maximum layers and successful first feeding. Fish Bull. 1975;73:453-62.

88. Peterman RM, Bradford MJ. Wind speed and mortality rate of a marine fish, the northern anchovy (Engraulis mordax). Science. 1987;235:354-6.

89. Ainley DG, Sydeman WJ, Parrish RH, Lenarz WH. Oceanic factors influencing distribution of young rockfish (Sebastes) in Central California: a predator's perspective. Cal Coop Ocean Fish Invest Rep. 1993;34:133-9.
90. Beaugrand G, Brander KM, Lindley JA, Souissi S, Reid PC. Plankton effect on cod recruitment in the North Sea. Nature. 2003;426:661-4.

91. Dorman JG, Powell TM, Sydeman WJ, Bograd SJ. Advection and starvation cause krill (Euphausia pacifica) decreases in 2005 Northern California coastal populations: implications from a model study. Geophys Res Lett. 2011;38:L04605.

92. Logerwell EA, Mantua N, Lawson PW, Francis RC, Agostini VN. Tracking environmental processes in the coastal zone for understanding and predicting Oregon coho (Oncorhynchus kisutch) marine survival. Fish Oceanogr. 2003;12:554-68.

93. Purcell JE, Breitburg DL, Decker MB, Graham WM, Youngbluth MJ, Raskoff KA (2001) Pelagic cnidarians and ctenophores in low dissolved oxygen environments: a review. In: Rabalais NN, Turner $\mathrm{RE}$ (eds) Coastal hypoxia: consequences for living resources and ecosystems. American Geophysical Union, Washington, D. C., pp. $77-100$

94. Decker MB, Breitburg DL, Purcell JE. Effects of low dissolved oxygen on zooplankton predation by the ctenophore Mnemiopsis leidyi. Mar Ecol Prog Ser. 2004;280:163-72.

95. Lynam CP, Gibbons MJ, Axelsen BE, Sparks CAJ, Coetzee J, Heywood BG, et al. Jellyfish overtake fish in a heavily fished ecosystem. Curr Biol. 2006;16:R492-3.

96. Brotz L, Cheung WWL, Kleisner K, Pakhomov E, Pauly D. Increasing jellyfish populations: trends in large marine ecosystems. Hydrobiologia. 2012;690:3-20.

97. Taylor AH, Allen JI, Clark PA. Extraction of a weak climatic signal by an ecosystem. Nature. 2002;416:629-32.

98. Stock CA, Dunne JP, John JG. Drivers of trophic amplification of ocean productivity trends in a changing climate. Biogeosci Discuss. 2014;11:11331-59.

99. Hazen EL, Jorgensen S, Rykaczewski RR, et al. Predicted habitat shifts of Pacific top predators in a changing climate. Nat Clim Chang. 2013;3:234-8.

100. Sydeman WJ, Mills KL, Santora JA, et al. Seabirds and climate in the California Current-a synthesis of change. Cal Coop Ocean Fish Invest Rep. 2009;50:82-104.

101. Jahncke J, Checkley DM, Hunt GL. Trends in carbon flux to seabirds in the Peruvian upwelling system: effects of wind and fisheries on population regulation. Fish Oceanogr. 2004;13:208-23.

102. Coetzee JC, Merkel D, de Moor CL, Twatwa NM, Barange M, Butterworth DS. Refined estimates of South African pelagic fish biomass from hydro-acoustic surveys: quantifying the effects of target strength, signal attenuation and receiver saturation. Afr $\mathrm{J}$ Mar Sci. 2008;30:205-17.

103. Salvadeo CJ, Lluch-Belda D, Gomez-Gallardo A, Urban-Ramirez J, MacLeod CD. Climate change and a poleward shift in the distribution of the Pacific white-sided dolphin in the northeastern Pacific. Endanger Species Res. 2010;11:13-9.

104. Bograd SJ, Lynn RJ. Physical-biological coupling in the California Current during the 1997-99 El Niño-La Niña cycle. Geophys Res Lett. 2001;28:275-8.

105. Chavez FP, Ryan J, Lluch-Cota SE, Niquen M. From anchovies to sardines and back: multidecadal change in the Pacific Ocean. Science. 2003;300:217-21.

106. Sydeman WJ, Santora JA, Thompson SA, Marinovic B, Di Lorenzo E. Increasing variance in North Pacific climate relates to unprecedented ecosystem variability off California. Glob Chang Biol. 2013;19:1662-75. 